\title{
The Relationship between Students, Attitudes toward Lecturer Teaching Methods and Learning Environment with Achievement Motivation (Descriptive Study of Management Students of STIE Dharma Agung)
}

\author{
Yeni Susilowati \\ State University of Jakarta, Indonesia \\ Received October 24, 2019; Revised January 21, 2020; Accepted February 25, 2020
}

Copyright $\subseteq 2020$ by authors, all rights reserved. Authors agree that this article remains permanently open access under the terms of the Creative Commons Attribution License 4.0 International License

\begin{abstract}
This study aims to determine whether: (1) there is a relationship between students' attitudes toward teaching methods of lecturers with learning achievement motivation, (2) there is a relationship between students' learning environments and learning achievement motivation. The population of this research is the 2017 and 2018 students of Management Study Program STIE Dharma Agung. A sample of 165 students was taken incidentally. Data collection is carried out by a questionnaire containing a closed question questionnaire. Data analysis techniques is Spearman's rank correlation analysis. The decision used to accept or reject alternative hypotheses has a significance level of 5\%. From the results of the analysis it can be concluded as follows: (1) there is no positive and significant relationship between students' attitudes toward teaching methods of lecturers and learning achievement motivation, which is based on the calculation of the calculated correlation coefficient values which show a correlation $r$ of -0.134 or a probability number of 0.086 with a significance level of 5\%. (2) there is no positive and significant relationship between the learning environment of students and learning achievement motivation, which is based on the calculated correlation coefficient which shows a correlation $r$ of -0.140 or a probability number of 0.072 with a significance level of $5 \%$.
\end{abstract}

Keywords Attitudes, Teaching Methods, Learning Environment, Achievement Motivation

\section{Introduction}

The teaching method has an important role in the teaching and learning process (Kedraka \& Rotidi, 2017; Takeuchi, Mori, Suzukamo, \& Izumi, 2019). The teaching method is a way that contains standard procedures for carrying out educational activities, especially the activity of presenting the subject matter to students. The creativity of lecturers in using varied teaching methods is very much needed in the teaching and learning process; this is done so that students are interested, happy and understand the lecture material. Students will easily understand the material presented by the lecturer. But in reality, I often found a number of lecturers in the subject of Human Resource Administration and Office Management Management Studies Program at STIE Dharma Agung, wherein the teaching and learning process only uses monotonous methods. For example, the subjects in Human Resource Administration and Office Management are only filled with lectures and practice questions in a row or even given only assignments and discussions. Students will feel bored and fed up with such conditions continuously.

Choosing teaching methods for a lecturer, must pay attention to several things, namely the suitability of the teaching methods used with the objectives and teaching materials; the suitability of the teaching methods used with student learning abilities; the ability of lecturers to use the method; suitability of teaching used with facilities available in schools; suitability of teaching used with the educational environment (Chikazinga, 2018; Duman, 2018; Tawafak, Romli, \& Alsinani, 2019).

Through observations over the past few weeks, a lecturer using teaching methods that are suitable for the material can make students pay attention to the material that will be taught by the lecturer. For example, the method used is by field observation and creating learning video content in working on both group and individual assignments. Here 
students will feel interested in the course and they feel that he must explore the material so that other friends come to understand the content they make about the material. Therefore, a teacher is expected to always provide teaching methods that motivate students to continue learning. Although there are weaknesses and strengths of each method, as a teacher must be able to make students motivated to learn in class.

Besides, teaching methods are another important component in the student learning environment. The environment is something that is around us that has certain meanings and relationships with individuals (Stone \& Surmitis, 2018). However, the environment as a basis for teaching is a conditional factor that influences individual behavior and is an important learning factor (Bravo, Catalán, \& Pina, 2018; Schultz \& Simpson, 2013).

The student learning environment is divided into three environments namely family or boarding environment, campus and community. The student learning environment is expected to increase learning motivation. A family or boarding environment is the environment that is closest to someone. A boarding environment can make someone motivated to learn. In the boarding environment, a person will feel calm because the place is the second place other than home. Boarding can make someone diligent but can also make someone indolent. For example, friends who have learning motivation will encourage other friends to learn too. Another case when boarding friends often do outside activities that are not related to learning such as traveling - spending time in a entertainment center. Also, indoor activities such as watching TV and e-sports (gameonline games) for a long time and so on will make learning motivation decrease, because the time that can be used for the use of learning and doing work will be used for less useful things.

Likewise, the campus and community environment can also make someone unmotivated in learning. For example, in a campus environment that is less humanistic and uncomfortable, it can make someone indolent to study on campus when the lecture time is over, because this unfavorable environment can reduce the desire of students to use their free time on campus. Likewise, in the community environment, we will be indolent to learn because we want to play with friends outside the campus environment.

The motivation of the achievement of someone occurs because of our attitude towards something, where we will feel comfortable, calm and passion in living it. In addition, it must be supported by an environment that makes a person feel enthusiastic about learning. Motivation will grow in someone if someone feels that the method used by the lecturer can foster a good attitude towards the course (Keziban Tekşan, 2019; Lotulung, Ibrahim, \& Tumurang, 2018). Besides the family environment or boarding, and the community must be able to provide a special time of learning for a student.
From the introduction above, the author will analyze "The Relationship Between Students' Attitudes to the Teaching Method of Lecturers and the Learning Environment with Motivation to Achieve Learning".

In this study, the formulation of the problem is: 1) Is there a relationship between students' attitudes toward teaching methods of lecturers and achievement motivation for learning? 2) Is there a relationship between the learning environment of students with learning achievement motivation?

The objectives of this research are 1) To find out whether there is a positive and significant relationship between students' attitudes toward teaching methods of lecturers and achievement motivation in learning; 2) To find out whether there is a positive and significant relationship between student learning environments with learning achievement motivation.

\section{Literature Review}

\subsection{Student Attitude}

Attitude is a tendency to react to a thing, person or object with likes dislikes or is indifferent (Herron \& Hennessey, 2019). Thus, in principle, attitude can be considered a student's tendency to act in a certain way. The tendency to react or someone's attitude towards something, people or objects can thus be three possibilities, namely (accept or like), dislike (reject or not happy) and indifferent attitude. Attitude is a reaction to the views or feelings of an individual towards a particular object. Although the object is the same, not all individuals have the same attitude; it can be influenced by individual circumstances, experiences, information, and needs of each individual are different. A person's attitude towards objects will shape individual behavior towards objects.

From some of the definitions above, it can be concluded that attitude is a reaction or response in the form of an assessment that arises from an individual on an object. Attitude can also be said as an expression of awareness of the environment. The process that begins the formation of attitude is the existence of objects around the individual giving stimulus which then affects the individual senses, the information captured about the object is then processed in the brain and elicits a reaction. Judgments that emerge, positive or negative, are influenced by prior information or individual personal experiences.

\subsection{Teaching Method}

The method is a comprehensive plan for presenting language learning materials regularly; there is no one contradictory part, and all of them are based on a certain approach (Kohan \& Costa Carvalho, 2019). The method is a systematic way of working to begin the implementation 
of assessment activity to achieve predetermined goals (Rustam, Santun Naga, \& Supriyati, 2019).

Based on this opinion it can be concluded that the learning method is complete and systematic planning in presenting subject matter. Learning methods are carried out regularly and gradually in different ways to achieve certain goals under different conditions.

\subsection{Learning Environment}

The learning environment is one part of the learning process to achieve learning goals, where the environment will affect teaching and learning activities in schools (Rustam et al., 2019). According to Wahyuningsih and Djazari the learning environment is an environment that influences the learning process both the physical and social environment. The environment will affect individuals and vice versa, individuals can also influence the learning environment such as facilities and infrastructure, the extent of the environment, lighting and noise have a great influence on the assessment of whether or not a pleasant learning environment so that it can affect motivation and the learning process. Comfortable classroom conditions will help students to more easily concentrate, obtain maximum learning results and be able to enjoy learning activities well.

Based on the description above, it can be concluded that the learning environment is the place of the learning process. The learning environment can influence the success of the learning process. The learning environment is not only inanimate objects that are around the place of learning, but the people who are in that place also include the learning environment.

\subsection{Achievement motivation}

Achievement motivation is the driving force to achieve the highest level of learning achievement for the sake of hope to himself (Philominraj, Jeyabalan, \& Vidal-Silva, 2017). Achievement motivation is a desire that exists in a person that drives that person to try to achieve a standard or measure of excellence. A measure of excellence is obtained by referring to the achievements of others, but also by comparing the achievements made previously. Achievement motivation is also interpreted as something that exists and characterizes a person's personality and is brought from birth which is then grown and developed through interaction with the environment. Achievement motivation is one's tendency to achieve success or obtain what is desired end goal, individual's involvement in a task, hope to succeed in a given task, and encouragement to face obstacles to do jobs quickly and precisely.

Based on the previous descriptions, it can be concluded that achievement motivation is the desire and encouragement that exists in a person to achieve a goal that is the hope of themselves so as to enable optimal achievement.

\section{Methodology/Materials}

This type of research is used by the existing problems, namely descriptive research is research that is limited to the effort to express the intentions and circumstances as they are only to reveal facts. Subjects in this study are students who are currently studying management programs and have received courses in Human Resource Administration and Office Management Management Study Programs at STIE Dharma Agung, while the object is student attitudes towards teaching methods of lecturers and student learning environments with motivation for learning achievement.

The population used in this research is the total number of units of the analysis of its characteristics. The population of this research was all students of management study program class of 2017 and 2018 as many as 177 students. Exidental Sampling was used, which is a sampling technique based on coincidence which amounts to as many as 165 .

Research variables are varied research objects or what is the focus of research. In this study there are three variables, namely the independent variable, which includes students' attitudes towards the teaching methods of lecturers (X1) and students' learning environments (X2). The dependent variable is learning achievement motivation $(\mathrm{Y})$.

Indicators used in the variable Student Learning Environment are 1) Family Environment includes how parents educate, family atmosphere, understanding parents, place of learning; 2) Campus Environment includes the interaction of students with students, Relationships between lecturers and students, State of the campus and 3) Community Environment includes socializing, Environment in the community. The indicators of students attitudes towards the teaching methods of lecturers include the Lecture Method, Discussion Method, Task Method, Question and Answer Method, Sociodrama Method, PBM. Howeverr, the variable Learning Achievement Motivation indicators include Motivation with student attitudes towards teaching methods, Motivation with student learning environments, Learning motivation.

Test The research instrument uses validity testing to find out whether the research instrument is valid or not and reliability testing which is an index that shows the extent of a measuring instrument. The reliability test uses a split internal consistency system with the Cronbach Alpha formula. In the data, analysis technique includes data description, normality test, and hypothesis testing using SPSS Version 25

\section{Results and Findings}

\subsection{Data Description}

\subsubsection{Students' Attitudes Toward Lecturer Teaching Methods}

The results of the statistical description test found that 
the average student had a student attitude toward teaching methods of 29.61 in the above classification, including high. While seen individually, of the 165 students who sampled as many as 19 or $11 \%$ had attitudes in the low classification, as many as 105 or $64 \%$ had an attitude in the high classification, and as many as 41 or $25 \%$ in the classification was very high, none of them had attitude in the classification is very low.

\subsubsection{Student Learning Environment}

The description statistical test results get an average of a student learning environment of $28.28 \%$, in the above classification including high. While seen individually, of the 165 students sampled as many as 31 or $19 \%$ had attitudes in the low classification, as many as 105 or $63 \%$ had an attitude in the high classification, and as many as 29 or $18 \%$ in the classification was very high, none of them had attitude in the classification is very low.

\subsubsection{Learning Achievement Motivation}

The description of statistical test results found that the average student had a learning achievement motivation of $36.39 \%$, in the above classification including high. While seen individually, of the 165 students who sampled as many as 2 or $1.22 \%$ had attitudes in very low classification, as many as 119 or $72.12 \%$ had attitudes in the low classification, as many as 40 or $24.24 \%$ had attitudes in high classification, and as many as 4 or $2.42 \%$ in the classification is very high.

\subsection{Data analysis}

\subsubsection{Normality Testing}

A normality test is carried out to determine the condition of each variable, whether it is normally distributed or not. This normality test used Kolmogorov Smirnov. The test results get the Kolmogorov Smirnov coefficient for variable student attitudes toward lecturer teaching methods by 0.836 with a probability of 0.487 , for student learning environment variables of 1.320 with a probability of 0.061 and the motivation variable for learning achievement is 2,039 with a probability of 0,000 . Of the three who have a probability of more than 0.05 , there are two variables, namely the student attitude variable and the student learning environment; then the variable is normally distributed. Whereas the variable of learning achievement motivation has a probability of less than 0.05 , then the distribution is not normal. This means that for further testing, nonparametric testing with Rank Spearman is performed. Analysis with the Kolmogorov Smirnov test was performed computationally through the SPSS Version 25 program.

\subsubsection{Hypothesis Testing}

Spearman's rank correlation analysis or grading correlation is used to answer research questions and at the same time relate to the first and second hypotheses. Assuming that the actual rank correlation coefficient s (= Rho s), will be zero with a significance level of $5 \%$, it can be tested by comparing the probability figures obtained from computational results with the significance level. If the probability is significantly below 0.05 , then $\mathrm{Ho}$ is rejected or there is a relationship between the $\mathrm{X}$ and $\mathrm{Y}$ variables, and vice versa. This level correlation test uses SPSS version 25 .

\subsubsection{First hypothesis}

The first hypothesis testing said that "there was a significant positive relationship between students' attitudes toward teaching methods of lecturers and achievement motivation for learning" used rank correlation from Spearman.

Based on the results of testing the hypothesis with Spearman's rank correlation, the $\mathrm{r}$ count value obtained 0.134 between students' attitudes toward teaching methods of lecturers and achievement motivation in learning. This figure shows a negative or weak correlation between students' attitudes toward teaching methods of lecturers with achievement motivation of learning at a significance level of $5 \%$.

To prove the rejection of the hypothesis, the next step is to test the correlation coefficient to test whether the value of $\mathrm{r}$ is significant or not, namely by comparing the probability number with a significance level of $5 \%$.

Based on the results of the calculation, the probability value of 0.086 is greater than 0.05 or a significant value> $5 \%$, then Ho fails to be rejected, which means there is no relationship between students' attitudes towards the teaching methods of lecturers and motivation for learning achievement. Therefore, it is stated that the more positive attitude of students towards the teaching methods of lecturers, the higher the motivation for learning achievement, is rejected.

\subsubsection{Second Hypothesis}

The first hypothesis testing said that "there is a significant positive relationship between the learning environment of students with achievement motivation in learning" used rank correlation from Spearman.

Based on the results of testing the hypothesis with Spearman's rank correlation, the $r$ count value obtained 0.140 between the learning environment of students with learning achievement motivation. This figure shows a negative or weak correlation between the learning environment of students with learning achievement motivation at a significance level of $5 \%$.

To prove the rejection of the hypothesis, the next step is to test the correlation coefficient to test whether the r-value is significant or not, by comparing the probability number with a significance level of $5 \%$.

Based on the calculation results, the probability number of 0.072 is greater than 0.05 or a significant value> $5 \%$, 
then Ho fails to be rejected, which means there is no relationship between the learning environment of students with learning achievement motivation is positive. It is state that the more positive the student learning environment, the higher the motivation to achieve learning, is rejected.

\subsection{Discussion}

\subsubsection{The relationship between students' attitudes toward} teaching methods of lecturers and achievement motivation in learning

From the results of the analysis, it is known that the first hypothesis states the relationship between students 'attitudes toward teaching methods of lecturers and achievement motivation to learn successfully failed, meaning that there is no significant positive relationship between students' attitudes toward teaching methods of lecturers and learning achievement motivation. This means that students' attitudes towards the learning methods conveyed by lecturers with achievement motivation have no positive relationship. This statement is based on the calculated correlation coefficient analysis which shows a correlation $r$ of -0.134 or a probability number of 0.086 with a significance level of 5\%, which is a significant value> of 0.05 . Student attitudes toward teaching methods of lecturers do not cause high student motivation and vice versa.

Various factors influence the method of learning, and one of the most important had become part of the attitude of students with achievement motivation, because achievement motivation is related to learning attitudes. Learning attitude is the tendency of behavior when someone learns academic matters. Learning attitude plays a role in shaping learning activities. A positive learning attitude is closely related to interests and motivation. Therefore, if the other factors are the same, students who have positive learning attitudes will learn more actively, thus achieving better results than those who have negative learning attitudes.

A learning attitude is the tendency of a person's behavior when he learns academic things. Learning attitude is also a reflection of student's behavior or judgment when learning academic matters. Scores obtained from the scale of student learning attitudes consisting of 3 aspects, namely: Student assessment of lecturer behavior, Student assessment of lecturers' teaching methods and methods in teaching, and Student's assessment of approval, goals, practice and educational requirements. The indicators are: (1) student assessment of lecturer behavior, (2) student evaluation of lecturer teaching and teaching methods, and (3) student assessment of educational approval, goals, practice and requirements.

A person's impulse to overcome obstacles in achieving goals makes individuals who have high achievement motivation shows greater effort and tenacity. Achievement motivation is the desire and encouragement made by students to achieve their particular success to obtain something that is the final goal and hopes to succeed in carrying out tasks that are given quickly and accurately (in the academic field). The indicators are (1) Responsibility, (2) Risk of Task Selection, (3) Creative-Innovative, (4) Paying Attention to Feedback, and (5) Success Oriented.

From the results of this study, the more positive the attitude of students towards teaching methods of lecturers, the lower the value of motivation to achieve learning or student attitudes toward teaching methods of lecturers followed by a decrease in the value of motivation to achieve learning. This shows that external factors influence student learning motivation (Ramli, 2018; Yulika, Rahman, \& Sewang, 2019). Achievement motivation is strongly influenced by external factors and internal factors, for example, the campus environment does not support them in learning, both within the campus environment and the environment around students can decrease learning motivation. In the learning process, the learning environment becomes something important. Besides the social environment in the classroom that does not support them in learning, can make their learning motivation change. For example, my classmates who always invite me to chat can reduce my attention to lecture material . Classrooms are crowded because students who talk with other friends can also make student concentration divided.

The results of the study said that students' attitudes towards teaching methods of lecturers reduce learning motivation, for this reason, awareness within students to learn must be increased. Therefore, it can be concluded that the attitude of students towards teaching methods lecturers have a negative relationship with achievement motivation to learn.

\subsubsection{The relationship between the learning environment of students with learning achievement motivation}

From the results of the analysis, it is known that the first hypothesis states that the relationship between the learning environment of students with achievement motivation has failed to be rejected, meaning that there is no significant positive relationship between the learning environment of students with learning achievement motivation. From the results of the analysis, significant negative results were obtained between the learning environment of students with learning achievement motivation. This statement is based on an analysis of the calculated correlation coefficient which shows a correlation $\mathrm{r}$ of -0.140 or a probability number of 0.072 with a significance level of 5\%, which is a significant value $>$ of 0.05 . A good learning environment does not cause high student motivation and vice versa.

The learning process must involve the role of the learning environment. Therefore, students will learn more about logic and social knowledge from their friends. Therefore, through the learning environment, students can interact with and share experiences that enable them to 
hone their ability to speak.

The learning environment is a factor that equally originates from outside the student self which usually has an indirect effect on improving learning achievement. However, the unavailability of facilities and a good learning environment can be a problem and a barrier to the learning process and achievement of motivation for good learning achievement because of the neglect of its availability. Achievement of good learning achievement motivation shows success in the learning process, and vice versa not achieving good learning achievement motivation shows less success in the learning process.

Thus, a good learning environment for the smooth learning process needs to be considered by each campus, because the fulfillment of facilities and a good environment can minimize learning difficulties experienced by students. The level of learning difficulties is low, creating a smooth learning process so that there is an increase in the motivation of students' learning achievement. The success or failure of learning in the classroom turned out to be very supported by environmental factors.

The environment should also be a matter that must be considered to improve the ability and motivation to achieve learning. The condition of this learning environment determines the smooth learning process on campus. If the learning environment is very supportive, then students will be more enthusiastic in the learning process. For example, a safe and comfortable atmosphere so that students can absorb what is taught by their lecturers and vice versa if environmental conditions are less supportive in the learning process students will feel uncomfortable and this will have an impact on student achievement motivation. This condition results in students merely going to college to listen to the material taught by the teacher without understanding the knowledge given, which causes low achievement motivation.

The learning environment on campus is a place and source of learning for each individual. A good learning environment can stimulate learning. Conversely, an unfavorable environment will cause the disturbing concentration of learning. Then every campus environment is expected to have a good and calm environment to support the implementation of a good learning process. The fulfillment of learning facilities such as infrastructure in learning and the existence of good learning environment conditions can support the learning process so that activities take place effectively and efficiently. Student learning success as a result that has been achieved in the learning process effort is something that students have in the form of ability and mastery of learning materials. Learning outcomes are results that indicate that students have done acts of learning which generally include knowledge, skills, and new attitudes that are expected to be achieved by students.

Judging from the results, the more positive / better the student learning environment, the lower the value of learning achievement motivation or good student learning environment followed by a decrease in the value of learning achievement motivation. This shows that internal factors influence students in learning (Izci, 2016; Ramli, 2018). For example, compulsion, physical condition, interests, intelligence and so on can decrease their motivation. To increase motivation for learning, a student must have the will and support of the closest people such as parents and family. With a strong will from within oneself and the support of those closest to you, the motivation to learn will grow by itself. It can be concluded that the learning environment of students has a negative relationship with learning achievement motivation.

\section{Conclusion}

This research succeeded in describing the relationship between student attitudes towards teaching methods of lecturers and students' learning environments with student achievement achievement motivation in the Management Study Program at STIE Dharma Agung Bekasi. Based on these findings, conclusions can be drawn as follows:

1. There is no significant positive relationship between students' attitudes toward teaching methods of lecturers with learning achievement motivation. This can be seen from the calculated correlation coefficient which shows the correlation $\mathrm{r}$ of -0.134 or a probability number of 0.086 with a significance level of $5 \%$, which is a significant value $>$ of 0.05 .

2. There is no significant positive relationship between the learning environments of students with learning achievement motivation. This can be seen from the calculated correlation coefficient which shows the correlation $\mathrm{r}$ of -0.140 or a probability number of 0.072 with a significance level of $5 \%$, which is a significant value $>$ of 0.05 .

\section{Acknowledgements}

This research is supported by STIE Dharma Agung Private University.

\section{REFERENCES}

[1] Bravo, R., Catalán, S., \& Pina, J. M. (2018). Analysing teamwork in higher education: an empirical study on the antecedents and consequences of team cohesiveness. Studies in Higher Education, 5079(January), 1-13. https://doi.org/10.1080/03075079.2017.1420049

[2] Chikazinga, W. W. N. (2018). Perceptions of lecturers of student evaluations of their teaching. International Education Journal, 17(4), 36-48. 
[3] Duman, B. (2018). Self Assessments of the Prospective Teachers about the Teaching Materials They Have Designed. World Journal of Education, 8(6), 165. https://doi.org/10.5430/wje.v8n6p165

[4] Herron, J. P., \& Hennessey, M. N. (2019). Evaluation of Student's Attitude Toward Science in Indonesia. Open Journal for Educational Research, 3(2), 39-52. https://doi.org/10.32591/coas.ojer.0302.01039h

[5] Izci, K. (2016). Internal and External Factors Affecting Teachers' Adoption of Formative Assessment to Support Learning. Tojet - The Turkish Online Journal of Educational Technology, 10(8), 2541-2548.

[6] Kedraka, K., \& Rotidi, G. (2017). University Pedagogy: A New Culture is Emerging in Greek Higher Education. International Journal of Higher Education, 6(3), 147. https://doi.org/10.5430/ijhe.v6n3p147

[7] Keziban Tekşan. (2019). The Perceptions o f Students Studying in the Faculty of Education Towards Reading in Terms o f Therr Read ing Motivations. International Journal of Progressive Education, 15(5), 0-2. https://doi.org/10.29329/ijpe.2019.212.12

[8] Kohan, W. O., \& Costa Carvalho, M. (2019). Finding Treasures: Is the Community of Philosophical Inquiry a Methodology? Studies in Philosophy and Education, 38(3), 275-289. https://doi.org/10.1007/s11217-019-09659-y

[9] Lotulung, C. F., Ibrahim, N., \& Tumurang, H. (2018). Effectiveness of Learning Method Contextual Teaching Learning (CTL) for Increasing Learning Outcomes of Entrepreneurship Education. Turkish Online Journal of Educational Technology - TOJET, 17(3), 37-46.

[10] Philominraj, A., Jeyabalan, D., \& Vidal-Silva, C. (2017). Visual Learning: A Learner Centered Approach to Enhance English Language Teaching. English Language Teaching, 10(3), 54. https://doi.org/10.5539/elt.v10n3p54

[11] Ramli, N. (2018). External Factors , Internal Factors and Self-Directed Learning Readiness. Journal of Education and E-Learning Research, 5(1), 37-42. https://doi.org/10.20448/journal.509.2018.51.37.42

[12] Rustam, A., Santun Naga, D., \& Supriyati, Y. (2019). Sensitivity and Accuracy of the Mantel-Haenszel Method and Standardization Method: Detection of Item Functioning Differential. International Journal of Education and Literacy Studies, 7(3), 28. https://doi.org/10.7575/aiac.ijels .v. 7 n. 3 p. 28

[13] Schultz, E. K., \& Simpson, C. G. (2013). Factors influencing teacher behavior with students with diverse learning and behavioral needs factors that influence teacher behavior with students with diverse learning and behavioral needs in inclusive classrooms. Journal of the American Academy of Special Education Professionals, (spring/summer), 118131. Retrieved from https://eric.ed.gov/?id=EJ1135529

[14] Stone, B., \& Surmitis, K. (2018). Educator Perceptions of Student Ownership and Self-Authorship: Building a Connective Framework between Two Constructs. International Journal of the Whole Child, 3(2), 19-24.

[15] Takeuchi, N., Mori, T., Suzukamo, Y., \& Izumi, S.-I. (2019). Activity of Prefrontal Cortex in Teachers and Students during Teaching of an Insight Problem. Mind, Brain, and
Education, 13(3), 167-175. https://doi.org/10.1111/mbe.12 207

[16] Tawafak, R. M., Romli, A. M., \& Alsinani, M. J. (2019). Student assessment feedback effectiveness model for enhancing teaching method and developing academic performance. International Journal of Information and Communication Technology Education, 15(3), 75-88. https://doi.org/10.4018/IJICTE.2019070106

[17] Yulika, R., Rahman, U., \& Sewang, A. M. (2019). The Effect of Emotional Intelligence and Learning Motivation on Student Achievement. 39(1), 1-8. https://doi.org/10.2991/ic amr-18.2019.94 